\title{
Explosive style, magma degassing and evolution in the Chaimilla eruption, Villarrica volcano, Southern Andes
}

\author{
L. Pioli $^{1}$ - L. Scalisi ${ }^{1}$ - L. Costantini ${ }^{1}$ - A. Di Muro ${ }^{2}$ - C. Bonadonna ${ }^{1} \cdot$ J. Clavero $^{3}$
}

Received: 7 February 2015 / Accepted: 20 September 2015 /Published online: 5 October 2015

(C) Springer-Verlag Berlin Heidelberg 2015

\begin{abstract}
Villarrica (Chile) is a basaltic stratovolcano, currently in an open-conduit condition. It now has relatively frequent Strombolian and effusive eruptions, but it had large explosive eruptions in prehistoric times. Among them, the most recent eruption was Chaimilla, which occurred about 3100 years ago and produced deposits that indicate complex, multiphase eruptive dynamics. Significant differences in mineralogy and glass compositions of the erupted scoria suggest the eruption was fed by two distinct magma batches with similar bulk compositions but distinct crystallization and degassing histories. The lower sequence scoria has a complex crystal assemblage with several crystal populations produced by mixing between a relatively degassed magma containing $\mathrm{Fo}_{75-79}$ olivine, normally or reversely zoned plagioclase $\left(\mathrm{An}_{70-94}\right)$ and augite (type 1 magma), and a subordinate volume of more-primitive and more volatile-rich magma rising from depth (type 2 magma) and carrying normally zoned plagioclase and higher- $\mathrm{Mg}\left(\mathrm{Fo}_{81-85}\right)$ olivine crystals. Type 2 magma was the main component emitted during the larger and more explosive eruptive phase that deposited the upper
\end{abstract}

Editorial responsibility: J. Fierstein

Electronic supplementary material The online version of this article (doi:10.1007/s00445-015-0976-1) contains supplementary material, which is available to authorized users.

L. Pioli

laura.pioli@unige.ch

1 Departement des Sciences de la Terre, Universitè de Genéve, Rue des Maraîchers 13, 1205 Genéve, Switzerland

2 Observatoire Volcanologique du Piton de la Fournaise, IPGP, La Plaine des Cafres, La Réunion, France

3 Escuela de Geologia, Universidad Mayor, Providencia, Santiago, Chile sequence. The Chaimilla eruption occurred under closedvent conditions and was fed by water-rich magmas. When compared with the petrological features of the magma currently erupted at Villarrica, which has slightly more-evolved bulk compositions, lower crystal content and lower water content, these results suggest that the evolution in eruptive style of the volcano from highly explosive to a lava lake/Strombolian activity corresponds to significant changes in the shallow plumbing system (which is now at much shallower depths); these plumbing-system changes were not associated with significant changes in the parental magma compositions.

Keywords Basalt explosivity $\cdot$ Melt inclusion $\cdot$ Chilean volcanism

\section{Introduction}

Magmatic volatiles and degassing play important roles in explosive eruptions because they influence magma properties, fragmentation and eruptive styles (Wilson et al. 1980; Melnik 2000; Cervantes and Wallace 2003; Del Carlo and Pompilio 2004; Di Muro et al. 2004; Goepfert and Gardner 2010; Métrich et al. 2010). In particular, high initial volatile content and fast ascent rate favour explosivity (Cashman 2004). Degassing-induced crystallization of phenocrysts and microlites has been proposed as an additional process controlling pre-eruptive magma viscosity and, thus, explosivity (Blundy and Cashman 2005; Erlund et al. 2010).

Among basaltic systems, the role of volatiles in increasing explosivity is particularly relevant in volatile-rich magmas erupted in subduction settings. Several studies have recognized that basalts associated with highly explosive eruptions contain high initial water content (up to 6 wt.\%, Roggensack et al. 1997; Newman et al. 2000; Pichavant et al. 2002; Grove 
et al. 2005; Gurenko et al. 2005; Spilliaert et al. 2006; Kamenetsky et al. 2007; Johnson et al. 2008; Métrich et al. 2010), suggesting that pre-eruptive volatile content, degassing dynamics and the amount of volatiles available in the magma at fragmentation strongly correlate with eruptive style. The importance of pre-eruptive degassing and outgassing is particularly evident at volcanoes that display a wide range in eruptive styles, from quiet lava emission to violent (subplinian to Plinian) explosions, but only limited variation in bulk chemistry of the erupted magma. Among them, Villarrica volcano (Southern Chile) is a striking example because of its current Hawaiian-Strombolian eruption style associated with a summit lava lake and its large explosive eruptions in the recent past (Clavero and Moreno 2004; Silva Parejas et al. 2010; Costantini et al. 2011).

We present a petrological and geochemical study of wellexposed deposits from a recent basaltic explosive eruption of Villarrica volcano, Chile, the 3.1-ka Chaimilla deposit, which has a volcanic explosivity index (VEI) of 4 (Costantini et al. 2011). Our aim is to determine pre-eruptive conditions and magma histories. The new dataset on explosive products is then compared with available data on magma erupted in prehistorical and recent activity (Vargas et al. 1989; Witter et al. 2004).

\section{Geological setting and eruptive history}

Villarrica is a stratovolcano located in the Southern Chilean Andes (Fig. 1). It is the most active volcano of this segment of the Andes in historical times (Lara 2004). The central cone $(2847 \mathrm{~m})$ lies on the NW rim of a $6.5 \times 4.2 \mathrm{~km}$ caldera (Moreno et al. 1994), which formed during large-volume eruptions associated with emplacement of the Licán ignimbrite $\left(\sim 10 \mathrm{~km}^{3}, 13.8 \mathrm{ka} \mathrm{BP}\right)$ and the Pucón ignimbrite $\left(\sim 5 \mathrm{~km}^{3}, 3.5 \mathrm{ka} \mathrm{BP}\right)$. Both ignimbrites have basaltic-andesite composition (Lohmar et al. 2012; Silva Parejas et al. 2010). Villarica's historical eruptive activity is associated with the central cone and has been mainly effusive. However, its postcaldera activity has also been mildly explosive (Van Daele et al. 2014), producing both large pyroclastic density currents (PDCs) and tephra fallout (not dated, Clavero and Moreno 1994; Lara 2004; Moreno and Clavero 2006). After the last eruption in 1984-1985, which produced both lava fountains and lava flows, Villarrica volcano maintained open-conduit conditions and an intermittent summit lava lake with very limited magma emission (Witter et al. 2004; Gurioli et al. 2008). In addition, partial melting of the summit glacier has generated lahars, which caused several fatalities during the 1948-1949, 1963-1964 and 1971-1972 eruptions (Rivera et al. 2008; Castruccio et al. 2010).

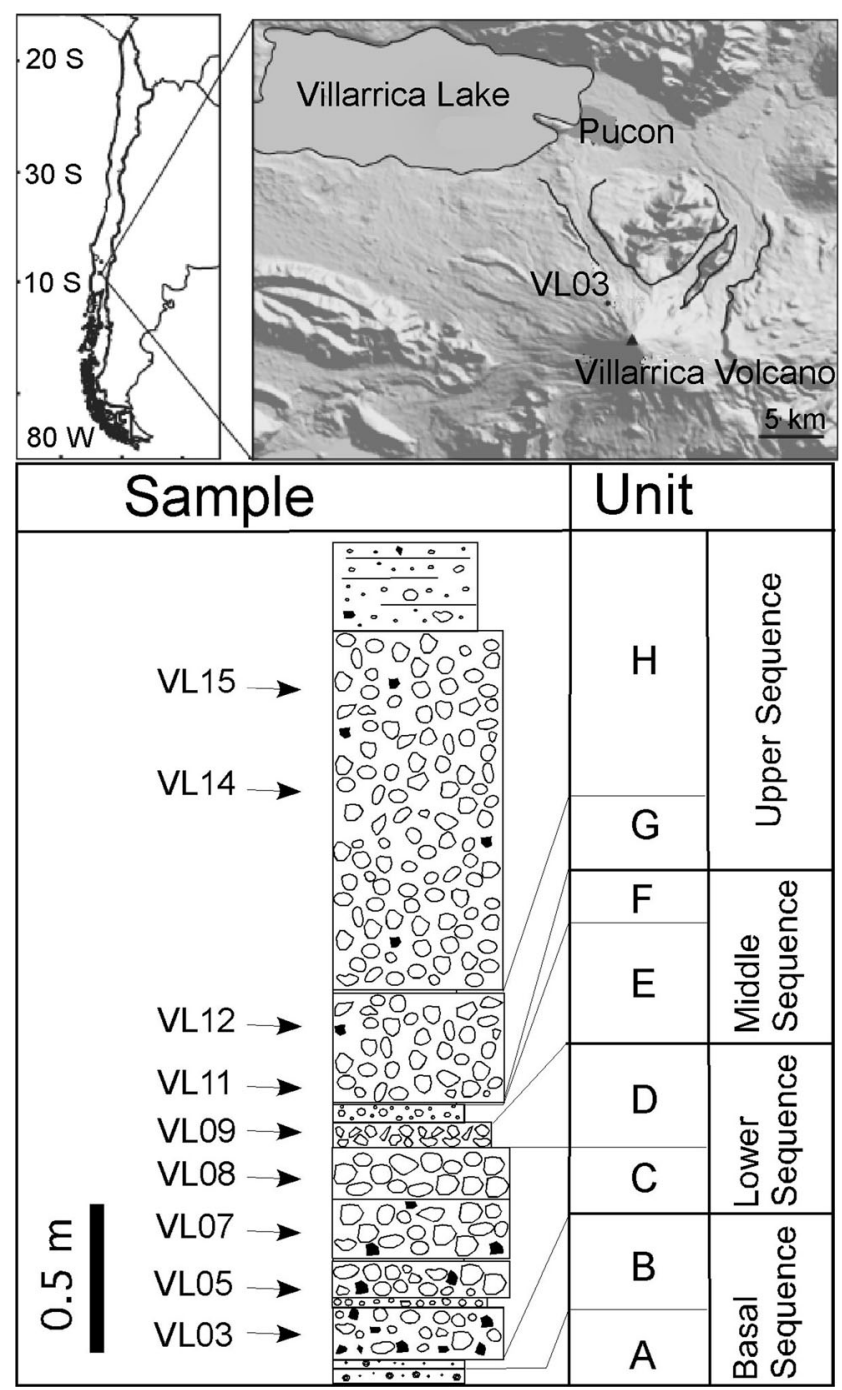

Fig. 1 a Location of Villarrica volcano. b Stratigraphy and sampling beds at the type outcrop. The outcrop is located about $3.2 \mathrm{~km} \mathrm{~N}$ of the summit crater, along the dispersal axis of tephra beds of the units $A, B, G$ and $H$

\section{The Chaimilla eruption}

The Chaimilla eruption ( 3.1 ka) produced one of the bestpreserved and most widely dispersed pyroclastic deposits of Villarrica volcano. The deposit is now exposed over an area of $250 \mathrm{~km}^{2}$ on the northern flank of the edifice and has a minimum volume of about $0.5 \mathrm{~km}^{3}$ (Costantini et al. 2011). The deposit comprises tephra from four different eruptive sequences (basal, lower, middle and upper, Fig. 1), which consist of several units (A-H) lying on top of the Pucón Ignimbrite, which was erupted 400 years earlier:

1. The basal sequence (BS) consists of two main ash and lapilli beds (units A, about $1.1 \times 10^{7} \mathrm{~m}^{3}$, and $\mathrm{B}$, about $7.2 \times 10^{6} \mathrm{~m}^{3}$ ), produced during the opening phase of the eruption by repeated explosions that dispersed ash and 
lapilli clasts up to several kilometres away from the vent, along with abundant lithic blocks and dense juvenile bombs in proximal areas.

2. The lower sequence (LS) consists of two fall deposits: C (about $1.4 \times 10^{8} \mathrm{~m}^{3}$ ) and D (about $1.3 \times 10^{7} \mathrm{~m}^{3}$ ). Unit $\mathrm{C}$ has wider dispersal than $\mathrm{D}$ and is made up of at least 20 different layers with distinct grain size (from coarse ash to bombs) and lithic contents. Unit D is a poorly dispersed, massive, moderately sorted layer, formed of glassy and highly vesicular scoria fragments. LS has been interpreted as the product of pulsatory activity associated with a series of discrete explosions of variable intensity or with a pulsating column (Costantini et al. 2011).

3. The middle sequence deposit consists of ash-rich, poorly sorted layers deposited by a PDC (unit E) and associated with a co-PDC ash layer (unit F), with a combined total volume of about $5 \times 10^{6} \mathrm{~m}^{3}$ (Costantini et al. 2011).

4. The upper sequence (US) consists of two units. Unit G is a structureless lapilli fall deposit, whereas unit $\mathrm{H}$ consists of a complex series of scoria lapilli fall beds and finely laminated PDC beds, which are inferred to result from partial to total collapse of the eruptive column. The total volume of the fall deposit is at least to $3.6 \times 10^{8} \mathrm{~m}^{3}$, and the PDC beds have a minimum volume one order of magnitude smaller.

\section{Methods}

\section{Sampling and sample preparation}

Samples were collected from lapilli fall layers of the Chaimilla deposit in a vertical section at a single outcrop located $3.2 \mathrm{~km} \mathrm{~N}$ of the vent (Fig. 1), along the downwind direction. In particular, we collected samples from units $\mathrm{C}$ and $\mathrm{D}$ in the LS and units $\mathrm{G}$ and $\mathrm{H}$ in the upper sequence. Whole-rock analyses were made on representative samples comprising 5-10 scoria lapilli collected from single stratigraphic layers.

Olivine crystals for melt inclusion studies were extracted from crushed scoria lapilli by hand picking from the size fraction $0.5-1.0 \mathrm{~mm}$. Crystals were embedded in epoxy and studied to identify primary, unfractured, glass inclusions. Doubly polished wafers were prepared for FTIR (fourier transform infrared Spectroscopy) analysis, whereas one-sided polished wafers were prepared for micro-Raman and electron microprobe analyses. FTIR and Raman analyses were performed before EMPA analysis. Further analyses of phenocrysts, melt inclusions and groundmass compositions were performed from thin sections made from single lapilli.

\section{Analytical methods}

Major-element compositions were analysed with a Philips PW2400 XRF spectrometer at the University of Lausanne (Switzerland). Loss on ignition (LOI) was determined using the gravimetric method corrected for $\mathrm{FeO}$ oxidation during ignition. Trace elements were analysed on fused glass discs by laser ablation inductively coupled plasma mass-spectrometry (LA-ICPMS) at the University of Lausanne (Switzerland), using a Lamba Physik GeoLas 200 M 193 nm ArF excimer laser ablation system interfaced to an Perkin Elmer ELAN 6100 DRC quadrupole ICPMS. Major-element compositions of phenocryst phases, olivine and plagioclase-hosted melt inclusions and matrix glass were measured using a JEOL JXA 8200 Superprobe at the University of Lausanne (Switzerland). For the olivinehosted glass inclusion analyses, we tested the mineralliquid equilibrium based on $\mathrm{Fe}-\mathrm{Mg}$ exchange coefficients $\left[K_{\mathrm{D}}(\mathrm{Fe}-\mathrm{Mg})^{\text {olv-liq }}=(\mathrm{FeO} / \mathrm{MgO})^{\text {olv }} /(\mathrm{FeO} / \mathrm{MgO})^{\mathrm{liq}}\right]$ in order to correct for olivine post-entrapment crystallization according to Toplis (2004) and Putirka (2008). To evaluate the $K_{\mathrm{D}}$, we calculated the $\mathrm{FeO} / \mathrm{Fe}_{2} \mathrm{O}_{3}$ ratio based on the composition of the selected (i.e. $\mathrm{Cr}_{2} \mathrm{O}_{3}>$ 13 wt. $\%, \mathrm{Al}_{2} \mathrm{O}_{3}>4$ wt. $\% ; \mathrm{FeO}_{\text {tot }}=13-22$ wt. $\% \mathrm{TiO}_{2}<$ 2.5 wt.\%) spinel crystals enclosed in olivines, following Maurel and Maurel (1982) and Danyushevsky and Sobolev (1996) and checking spinel reliability following Kamenetski et al. (Kamenetsky et al. 2001). Calculations produced an average value for $\mathrm{Fe}^{2} / \mathrm{Fe}^{3}$ of 2.5 and 3.9 for LS and US magmas, respectively. Crystallization of plagioclase-hosted melt inclusions was tested calculating $K_{\mathrm{D}}(\mathrm{Ca}-\mathrm{Na})^{\mathrm{Pl}-\mathrm{liq}}=(\mathrm{CaO} / \mathrm{NaO})^{\mathrm{Pl}} /$ $(\mathrm{CaO} / \mathrm{NaO})^{\text {liq }}$, following Hamada and Fuji (2007). Plagioclase composition is expressed as mole per cent of anortite, $\mathrm{An}=100 \times \mathrm{Ca} /(\mathrm{Ca}+\mathrm{Na}+\mathrm{K})$; olivine composition as mole per cent of forsterite, $\mathrm{Fo}=100 \times \mathrm{Mg} /(\mathrm{Mg}+$ $\mathrm{Fe})$. Augite composition was expressed as a function of wollastonite content, $\mathrm{Wo}=100 \times \mathrm{Ca} /(\mathrm{Mg}+\mathrm{Fe}+\mathrm{Ca})$, ferrosilite, $\mathrm{Fs}=100 \times \mathrm{Fe} /(\mathrm{Mg}+\mathrm{Fe}+\mathrm{Ca})$ and enstatite $\mathrm{En}=$ $100 \times \mathrm{Mg} /(\mathrm{Mg}+\mathrm{Fe}+\mathrm{Ca})$. Bulk rock $\mathrm{Mg} \#$ was calculated as $\mathrm{Mg} /\left(\mathrm{Mg}+\mathrm{Fe}_{\text {tot }}\right)$, whereas in glasses it was calculated as $\mathrm{Mg} /\left(\mathrm{Mg}+\mathrm{Fe}^{2+}\right)$.

Total dissolved water content of 37 olivine-hosted melt inclusions was also measured using confocal micro-Raman spectrometry at the Laboratory Pierre Süe of Saclay (France). Raman spectra were collected using a Renishaw inVia system connected to a Leica DMI microscope $(\times 100$ magnification) and equipped with a Peltier-cooled CCD detector. The concentrations of $\mathrm{H}$ - and $\mathrm{C}$-bearing (dissolved as carbonate only in our samples) species were determined in nine olivine-hosted melt inclusions by FTIR at the same laboratory. 


\section{Results}

\section{Bulk rock chemistry}

Chaimilla scoriae are basalts to basaltic andesites with $\mathrm{SiO}_{2}$ ranging from 51 to $53 \mathrm{wt}$ \% (Fig. 2). The compositional range is similar to some of the most mafic magmas erupted in prehistoric activity of Villarrica volcano (Vargas et al. 1989). It partially overlaps with the compositional range of lavas and scoria erupted in historical activity (Witter et al. 2004), but in general, it shows a wider variability towards more primitive compositions (Fig. 2). LS scoriae show slightly more-evolved compositions (average $\mathrm{Mg \#}$ of 0.65 ) than upper sequence (US) scoriae (average Mg\# of 0.68), but the most mafic sample (basalt with Mg\# of 0.73) was collected from unit C (LS). The role of olivine, pyroxene and plagioclase crystallization (which are the main phenocrysts in all Villarrica volcanics) in the differentiation of the Villarrica magmas can be analysed by comparing their $\mathrm{K} 2 \mathrm{O} / \mathrm{Na}_{2} \mathrm{O}, \mathrm{CaO} / \mathrm{Al}_{2} \mathrm{O}_{3}$ and $\mathrm{MgO}$ contents. The magmas have very similar $\mathrm{K}_{2} \mathrm{O} / \mathrm{Na}_{2} \mathrm{O}$ ratios (ranging from 0.25 to 0.18 ) and fit the general $\mathrm{MgO}-\mathrm{CaO} / \mathrm{Al}_{2} \mathrm{O}_{3}$ variation trend of Villarrica magmas (Fig. 3), suggesting that the magmas erupted at Villarrica were derived from the same parental magmas through different degrees of crystal fractionation of olivine followed by clinopyroxene and minor plagioclase. Trace-element concentrations confirm the subduction slab signature of these magmas and show similar patterns with respect to other magmas erupted from the Chilean Southern Volcanic Zone (Wehrmann et al. 2014), having MORBnormalized patterns with $\mathrm{Pb}, \mathrm{Ba} \mathrm{U}$ and $\mathrm{Sr}$ peaks, and troughs at $\mathrm{Nb}$ and $\mathrm{Ta}$ (Fig. 4). Chaimilla scoria has higher $\mathrm{Ba} / \mathrm{Nb}$ (103-159) and $\mathrm{Sr} / \mathrm{Ce}(25-35)$ ratios than do historical lava and scoria $(59-100 ; 11-22$, respectively) or those from older eruptions $(62-106 ; 22-32)$ with similar compositions previously measured by Vargas et al. (1989) Witter et al. (2004) and Wehrmann et al. (2014). These data suggest a slightly larger slab fluid component in the Chaimilla magmas with respect to current erupted magma compositions (Fig. 5).

\section{Petrography and mineralogy}

All Chaimilla juvenile products are porphyritic, containing phenocrysts of plagioclase, olivine, clinopyroxene and rare chromian spinels: we infer a paragenesis similar to that for other major eruptions of Villarrica (Vargas et al. 1989; Lohmar et al. 2005, 2012). Glomero-porhyritic clusters are common in scoria from all units, and suggest the following phenocryst crystallization order: Mg-rich olivine, Mg-poorer olivine + An-rich plagioclase + pyroxene, An-poor plagioclase. Juvenile clasts from the US are characterized by lower phenocryst contents (11-18 vol.\%, vesicle-free) than in LS clasts (20-25 vol.\%, vesicle-free).

Plagioclase is the main phenocryst. It is more abundant in the lower sequence (LS) scoria (about 20 vol.\%) than in the US scoria (about 12 vol.\%). Crystals range from euhedral to subhedral in both LS and US (Fig. 6); they are typically $1.5 \mathrm{~mm}$ in size reaching a maximum size of $3 \mathrm{~mm}$. The total compositional variability of plagioclase phenocrysts is large, ranging from $\mathrm{An}_{67}$ to $\mathrm{An}_{94}$. Crystals from units $\mathrm{C}$ and $\mathrm{D}$ display the largest compositional variability and are generally zoned; most crystals have An-rich (84 to 94 mol\%) cores, and more-evolved compositions rimward $\left(\mathrm{An}_{70-82}\right)$. External rim compositions range from $\mathrm{An}_{69}$ to $\mathrm{An}_{73}$. These crystals are grouped as type 2 plagioclases (Figs. $6 \mathrm{c}$ and $7 \mathrm{a}$ ). A subordinate fraction of crystals (type 1 plagioclase, Figs. $6 \mathrm{~d}$ and $7 \mathrm{a}$ ) is reversely zoned ( $\mathrm{An}_{73-82}$ cores and $\mathrm{An}_{81-85}$ rims); some crystals from unit $\mathrm{D}$ show complex zoning (patchy or oscillatory) or resorbed rims. Phenocrysts from units $\mathrm{G}$ and $\mathrm{H}$ have more
Fig. 2 Variation diagrams showing $\mathrm{SiO}_{2}$ compositions versus a $\mathrm{MgO}, \mathbf{b} \mathrm{K}_{2} \mathrm{O}, \mathbf{c} \mathrm{CaO}$ and d $\mathrm{Na}_{2} \mathrm{O}$ of Chaimilla bulk scoria (open red squares LS samples; solid red squares US samples) compared with bulk rock composition from recent (solid black squares) and prehistoric (open black squares) activity (data from Witter et al. 2004; Vargas et al. 1989 respectively). Chaimilla whole-rock composition data from Costantini et al. (2011) have been also included. Crosses on the top right indicate the measurement error

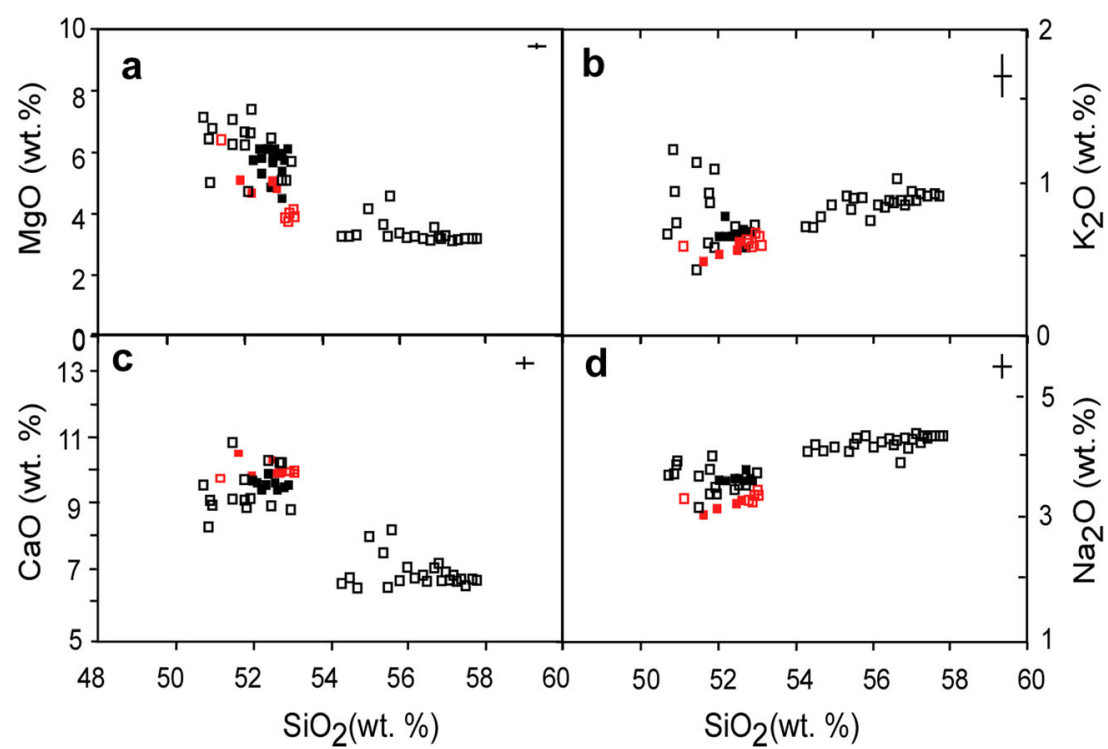




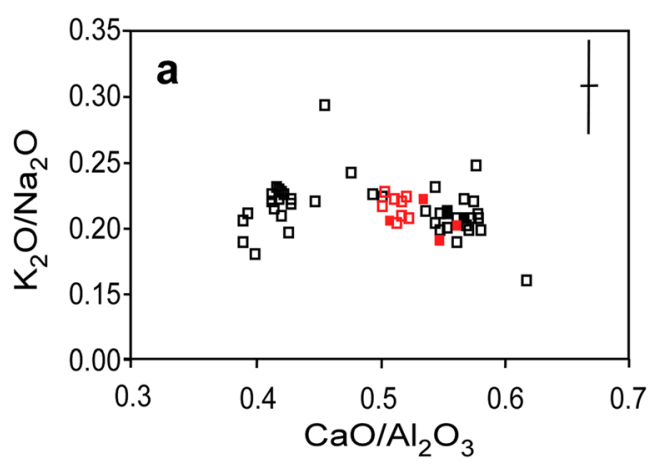

Fig. 3 Variation diagrams showing compositional variations of $\mathbf{a} \mathrm{K}_{2} \mathrm{O}$ / $\mathrm{Na}_{2} \mathrm{O}$ versus $\mathrm{CaO} / \mathrm{Al}_{2} \mathrm{O}_{3}$ and $\mathbf{b} \mathrm{MgO}$ versus $\mathrm{CaO} / \mathrm{Al}_{2} \mathrm{O}_{3}$ for bulk rock compositions of magmas erupted by Villarrica volcano. Symbols and

uniform zoning patterns including $\mathrm{An}_{94-85}$ cores and $\mathrm{An}_{82-66}$ rims, similar to type 2 plagioclase compositions. In all units, plagioclase microlite compositions range from $\mathrm{An}_{69}$ to $\mathrm{An}_{61}$; similar compositions also characterize an external, up to $15-\mu \mathrm{m}$-thick rim of some phenocrysts (Fig.6c).

Olivine crystals makeup only $1-3$ vol. $\%$ of the Chaimilla clasts and are usually euhedral to subhedral with sizes averaging between 1.0 and $1.5 \mathrm{~mm}$ in LS and $\leq 1 \mathrm{~mm}$ in the US (Figs. 6a, b and 7b). Larger crystals commonly contain glass inclusions. Most phenocrysts, microphenocrysts and groundmass crystals from unit $\mathrm{C}$ have homogeneous compositions ranging from $\mathrm{Fo}_{72}$ to $\mathrm{Fo}_{78}$, with the main mode at $\mathrm{Fo}_{78}$. Only a small proportion of crystals display a magnesian core $\left(\mathrm{Fo}_{80-}\right.$ 82); a few phenocrysts, with resorbed rims, have Mg-rich compositions $\left(\mathrm{Fo}_{81-83}\right)$. All crystals measured from unit D scoria have homogeneous compositions $\left(\mathrm{Fo}_{75}-78\right)$. Phenocrysts from units $\mathrm{G}$ and $\mathrm{H}$ are commonly normally zoned with cores ranging from $\mathrm{Fo}_{81}$ to $\mathrm{Fo}_{84}$ and $10-15-\mu$ m-thick rims with $\mathrm{Fo}_{75-79}$ compositions (Fig. 6a). Groundmass olivines have Fo-poor compositions (up to $\mathrm{Fo}_{69}$ ). Clear bimodality in olivine compositions allows for the distinction of two olivine types: type 1 including crystals with $\mathrm{Fo}_{74-79}$ compositions and type 2 including crystals with $\mathrm{Fo}_{80-85}$.

Clinopyroxene phenocrysts are less abundant than plagioclase and olivine (about 1 vol.\%), with size ranging from 0.5 to $1.5 \mathrm{~mm}$ in both sequences. Generally, they have euhedral

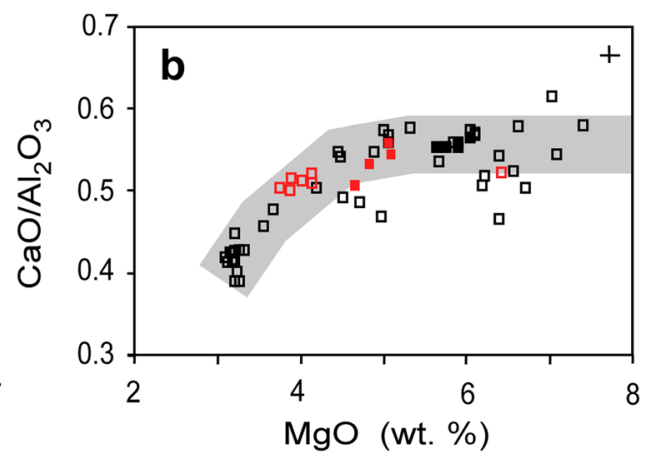

sources as in Fig. 2. Crosses on the right top indicate the measurement error. The shaded field in $\mathbf{b}$ underlines the main evolution trend

shapes (Fig. 6f). Pyroxenes only rarely contain glass inclusions, which have irregular shapes. Clinopyroxene phenocrysts display augitic composition with small heterogeneities within and among crystals $\left(\mathrm{Wo}_{38-45}, \mathrm{En}_{42-48}, \mathrm{Fs}_{8-14}\right.$, Fig.7c). As for olivine, unit $\mathrm{D}$ pyroxenes show the greatest uniformity with compositions of $\mathrm{En}_{44-46}$. Crystals are generally weakly zoned, with variation in En and Wo molar units always $<2 \%$.

Chromian spinels are rare and they usually appear enclosed within olivine crystals. Eleven chromian spinels embedded in olivine and two partially embedded within augite crystals were analysed in this study: they display variable compositions, with $\mathrm{Cr}_{2} \mathrm{O}_{3}$ ranging from 15 to $35 \mathrm{wt} . \%$. The two spinels within augite crystals show high $\mathrm{TiO}_{2}$ suggesting reequilibration with the melt. Spinels within olivine crystals have $\mathrm{Cr} \# \mathrm{Cr} /(\mathrm{Cr}+\mathrm{Al})$ between 0.38 and 0.56 . Crystals have similar $\mathrm{Fe}^{2+} / \mathrm{Fe}^{3+}$ ratios in lower units $(\mathrm{C}$ and $\mathrm{D})$ and larger variability in upper units $(\mathrm{G}$ and $\mathrm{H})$, which also appear correlated to variations of $\mathrm{Cr} \#, \mathrm{Mg} \#$ and olivine composition. This suggests that spinels embedded in type 1 olivines in LS crystallized at homogeneous oxygen fugacity conditions (Maurel and Maurel 1982) and that the spinels from the US recorded distinct oxygen fugacity conditions experienced by the magma during rise and differentiation corresponding to the crystallization of the two olivine types.

The scoria groundmass is heterogeneous, varies from honey to light brown glass, is poorly to moderately crystallized

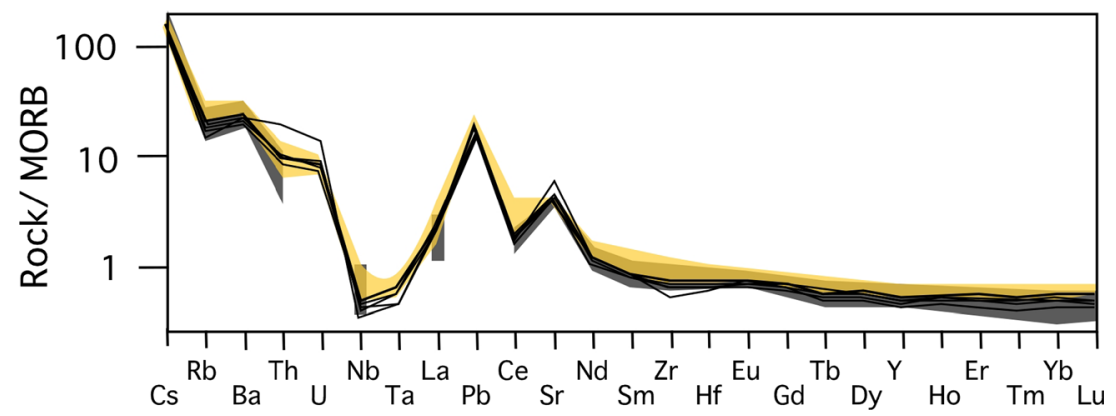

Fig. 4 N-MORB-normalized (after Sun and McDonough 1989) multielement variation diagram comparing Chaimilla scoria compositions with historical lavas and scoria (yellow field) and older deposits (grey field).
Data after Wehrmann et al. 2014; Witter et al. 2004 and Vargas et al. 1989 and this work 


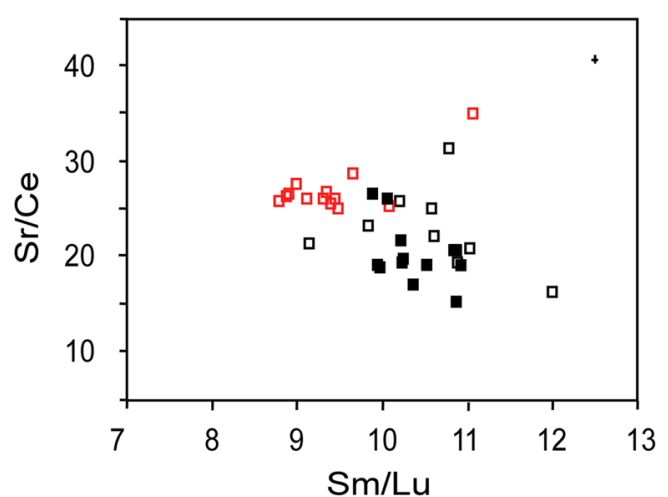

Fig. 5 Variation of $\mathrm{Sr} / \mathrm{Ce}$ and $\mathrm{Sm} / \mathrm{Lu}$ ratios in prehistoric, historic and Chaimilla scoria. Additional data from Wehrmann et al. (2014) and Vargas et al. (1989). Symbols as in Fig. 2. Cross on the right top indicates the measurement error

and is generally more crystalline in LS scoria than in US scoria. It contains microlites of plagioclase, clinopyroxene and oxides (Costantini et al. 2011). Enclaves of plagioclaserich altered or fresh lava were also found in some scoria clasts and probably represent xenolith fragments embedded in magmas.

\section{Textures of olivine and plagioclase-hosted glass inclusions}

The shape of olivine-hosted glass inclusions ranges from sub-spherical to elliptical or sub-angular. Inclusions occur either dispersed in the core of crystals or concentrated along growth zones. Their largest axis varies in size from a few to $150 \mu \mathrm{m}$ and they are generally more abundant in US than LS crystals. Most of the analysed glass inclusions are fully enclosed within the crystals, whereas only a few inclusions formed open embayments and only one was connected to the rim of the crystal by a thin neck (hourglass inclusion; Anderson 1991). Among the 47 analysed glass inclusions from both sequences, 15 contained small vesicles and two of them also contain an oxide crystal. The vapour bubbles are usually small, but they can represent a significant fraction of the melt inclusion, up to 30 vol. $\%$.

Plagioclase-hosted inclusions are more abundant, and more than 10 inclusions can occur within the same crystal. Some plagioclases display sieve structures with abundant irregular, elliptical or spherical closed glass inclusions. Sieve textures and skeletal shapes are common within plagioclase with compositions $\mathrm{An}_{87-82}$. Larger inclusions have generally irregular shapes, and display large vesicles whose volume can occupy up to $80-90 \%$ of the entire inclusion; smaller inclusions have sub-angular shapes and only rarely contain bubbles. All plagioclase-hosted inclusions are microlite-free.

\section{Olivine-hosted inclusion compositions}

Compositions of olivine-hosted glass inclusions and matrix glasses are shown in Figs. 8, 9 and 10. The inclusions from the US and LS follow the same covariation trends for major oxides (Fig. 8) but are distinct for volatile species (Fig. 10).

Glass inclusions have basaltic to basaltic-andesite compositions, which overlap most of the Villarrica volcanics (Figs. 2 and 8) and mirror the compositional variability of the hosting crystals. Inclusions trapped in US olivine are more primitive than bulk rock compositions.

Parallel variation of $\mathrm{CaO} / \mathrm{Al}_{2} \mathrm{O}_{3}$ and $\mathrm{K}_{2} \mathrm{O} / \mathrm{Na}_{2} \mathrm{O}$ ratios suggests that the most primitive inclusions from $\mathrm{US}\left(\mathrm{CaO} / \mathrm{Al}_{2} \mathrm{O}_{3}\right.$ between 0.71 and $0.60, \mathrm{MgO}$ between 8 and 5 wt.\%, Fig. 9) differentiated first by crystal fractionation of olivine, while crystallization of plagioclase became important during crystallization of more-evolved LS olivines, whose inclusions define a liquid line of descent marked by a linear increase in $\mathrm{K} 2 \mathrm{O} / \mathrm{Na}_{2} \mathrm{O}$ with decreasing $\mathrm{CaO} / \mathrm{Al}_{2} \mathrm{O}_{3}$.

The water contents of the olivine-hosted glass inclusions are shown in Fig. 10a. Covariation trends of $\mathrm{H}_{2} \mathrm{O}$ and major elements and similar Raman and FTIR results suggest that dissolved water content in MI was not significantly affected by bubble formation. Water content as measured with the Raman technique varies from 1.7 to $3.1 \mathrm{wt} . \%$. The nine inclusions analysed with FTIR techniques had water contents ranging from 1.5 to 2.7 wt. $\%$, whereas $\mathrm{CO}_{2}$ concentrations were above the detection limit (50 ppm) in only three inclusions, and ranged from 70 to $320 \mathrm{ppm}$. Analyses made on the same inclusions with the two techniques gave concentrations that differ by 10 to $30 \%$, with the exception of one sample where the difference is more significant.

Inclusions hosted in US type 2 olivine crystals have water contents ranging from 2.4 to $3.1 \mathrm{wt} . \%$, roughly decreasing with decreasing Fo content (Fig. 10a). $\mathrm{H}_{2} \mathrm{O} / \mathrm{K}_{2} \mathrm{O}$ ratios are higher and more variable in US scoria than in LS scoria. When compared with $\mathrm{CaO} / \mathrm{Al}_{2} \mathrm{O}_{3}$ ratios, inclusions define a degassing trend which we infer is associated with olivine and pyroxene, and then mostly with plagioclase, crystallization (Fig. 11a).

Measured S and $\mathrm{Cl}$ contents are up to 1400 and $180 \mathrm{ppm}$, respectively. $\mathrm{S}$ content is positively correlated with $\mathrm{Mg}$ in olivine, whereas $\mathrm{Cl}$ content shows very minor variations (Fig. 10b, c). S/Cl ratios decrease with decreasing water and $\mathrm{MgO}$ contents, suggesting that it was not significantly affected by boundary-layer effects (Baker 2008) and can be correlated with water degassing (Fig. 11b, c).

\section{Plagioclase-hosted inclusion compositions}

Plagioclase-hosted melt inclusions show lower variability than do olivine-hosted inclusions, fitting in the basalticandesite and andesite compositional fields, partially 

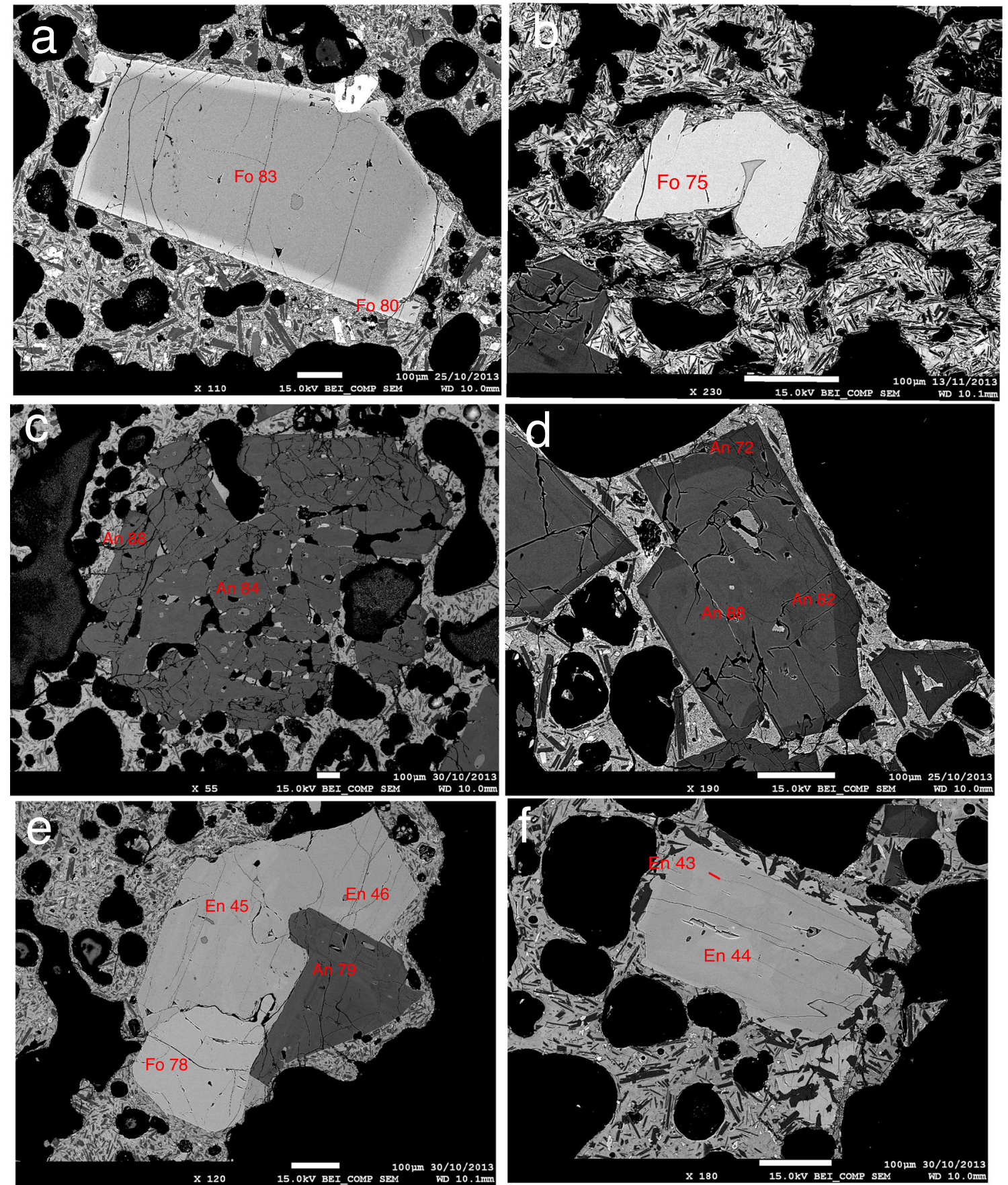

Fig. 6 SEM backscattered images of mineral phases of Chaimilla scoriae. a Euhedral type 2 olivine with Fo-poor rim, unit $\mathrm{H}$ scoria. b Skeletal, homogeneous, type 1 olivine, unit C scoria. c Skeletal, type 1 plagioclase, reversely zoned, unit C scoria. d Euhedral, normally zoned

overlapping groundmass compositions (Fig. 8). No evident growth rims were detected around glass inclusions in any of the analysed plagioclase crystals. Uncorrected compositions show Kd with the host plagioclase crystals ranging from 0.05 to 0.35 , increasing with $\mathrm{Ab}$ content of the host crystal, along the same trend for most inclusions (Fig. 12). As Kd plagioclase-liquidus varies with $\mathrm{T}, \mathrm{P}$ and water content type 2 plagioclase with multiple melt inclusions, unit $\mathrm{H}$ scoria. e Glomeroporphyre with clinopyroxene, type 1 olivine and An-poor plagioclase (type 1), unit D scoria. f Euhedral clinopyroxene, unit D scoria. Scale bars are $100 \mu \mathrm{m}$ long

(Hamada and Fuji 2007), it is expected to change during magma crystallization and degassing. The Chaimilla variability trend however, compared with the empirical relationship suggested by Hamada and Fuji (2007), suggests that Kd was mainly controlled by thermal effects, and that most of the inclusions retained pristine compositions and were not significantly affected by post-entrapment modification. For this 
a

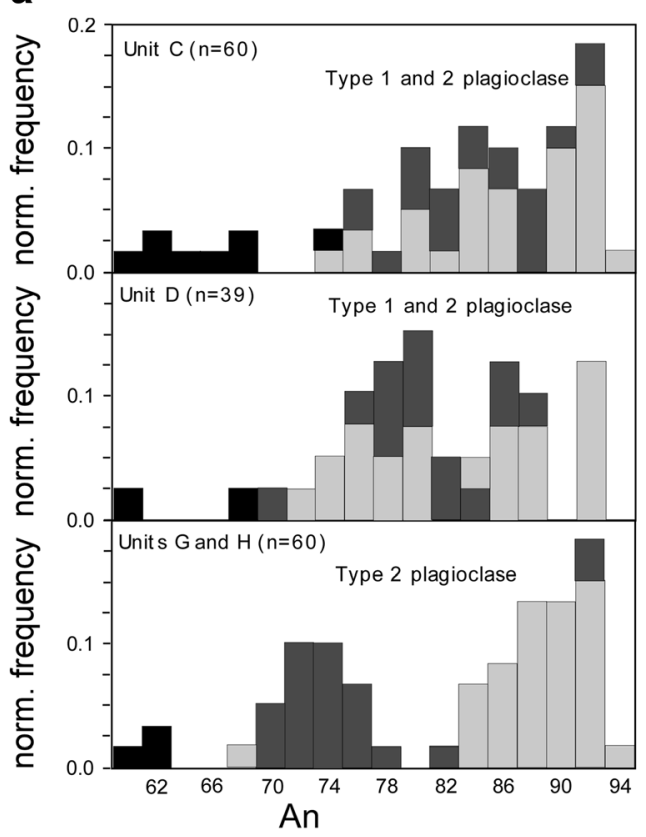

Fig. 7 Compositional variation of Chaimilla phenocrysts. a Plagioclase compositions; dark grey, light grey and black rectangles refer to rim, core and microlite compositions, respectively. b Olivine compositions (from both single grains of olivine crystals prepared for Raman and FTIR b

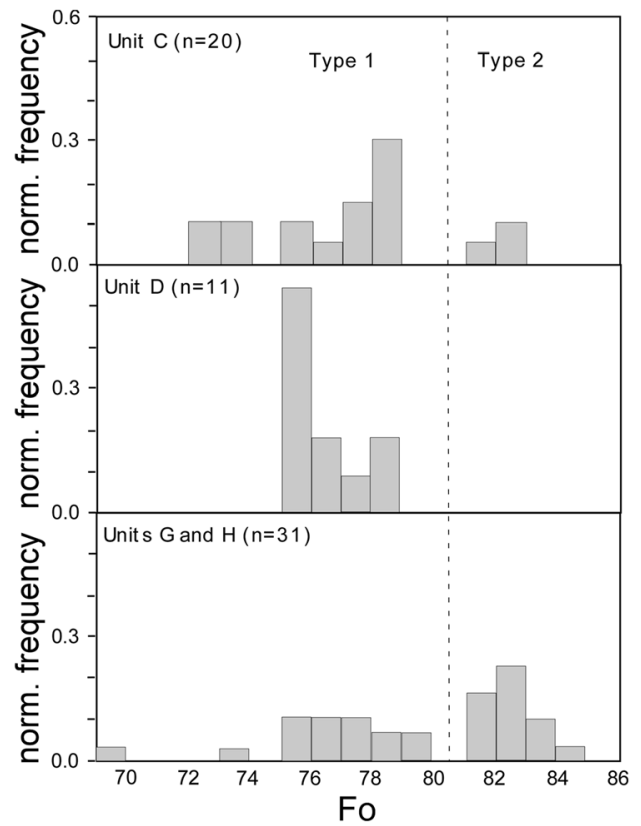

C

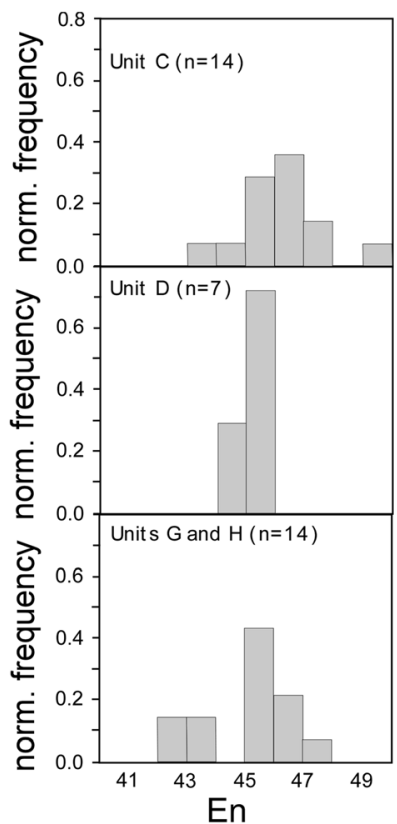

analysis and from olivines in thin sections) and clinopyroxene compositions. Norm. frequency (normalized frequency) $=$ number of crystals in each class divided by the total number of analysed crystals

reason, the few inclusions that do not fit the main trend have been disregarded from further calculations. MI compositions follow the same trends of the olivine-hosted inclusions analysed in the same units (Figs. 9 and 11).

$\mathrm{S}$ and $\mathrm{Cl}$ have maximum concentrations of 1200 and $900 \mathrm{ppm}$, respectively. Inclusions hosted in LS plagioclase follow similar trends to those of olivine-hosted inclusions (Fig. 8c). Most inclusions hosted in US, An-rich, plagioclase have very low $\mathrm{S}$ content and $\mathrm{S} / \mathrm{Cl}$ ratios with respect to olivine- hosted inclusions from the same scoria (Fig. 11c).
Plagioclase crystallization occurred during (and was likely promoted by) water degassing as suggested by the variability of $\mathrm{S} / \mathrm{Cl}$ ratios, which is comparable with that in olivine-hosted melt inclusions.

\section{Groundmass glasses}

The groundmass of scoria clasts commonly contains numerous microlites. Analyses were limited to crystal-free glass areas, and only partially reflect real groundmass
Fig. 8 Variation diagrams showing compositional variations of $\mathrm{SiO}_{2}$ versus a $\mathrm{MgO}$, b $\mathrm{K}_{2} \mathrm{O}$, c $\mathrm{CaO}$ and $\mathbf{d} \mathrm{Na}_{2} \mathrm{O}$, for olivinehosted melt inclusions (black dots), plagioclase-hosted glass inclusions (green dots), bulk scoria (red squares) and matrix glasses (blue triangles). Open symbols LS samples, closed symbols US samples. The grey line on Fig. 6a show the liquid line of descent calculated with MELTS simulations. Crosses on the right top indicate the measurement error

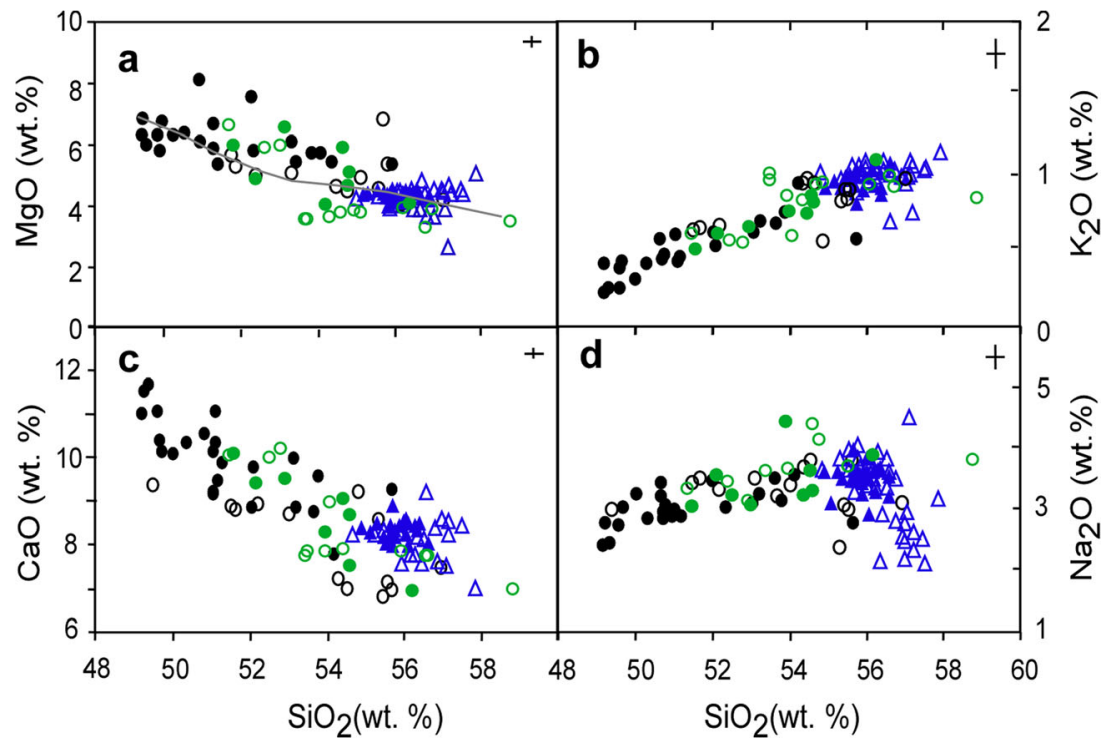




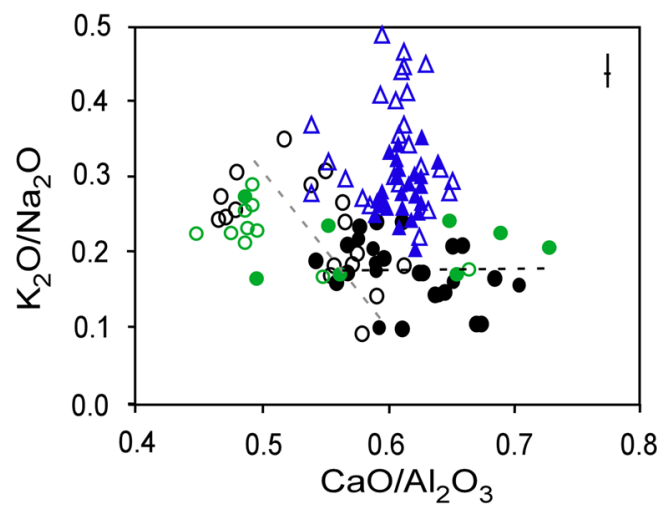

Fig. 9 Variation of $\mathrm{K}_{2} \mathrm{O} / \mathrm{Na}_{2} \mathrm{O}$ vs. $\mathrm{CaO} / \mathrm{Al}_{2} \mathrm{O}_{3}$ in glass inclusions and glassy groundmass. Symbols as in Fig. 8. Cross at the right top indicate the measurement error

compositional variation. Compositions fit the liquid line of descent defined by the same covariation trend of glass inclusions and match the bulk compositions of the more-evolved magmas erupted at Villarrica in Holocene times. With respect to Villarrica historical magmas, Chamilla groundmass glasses differ in having lower $\mathrm{CaO}, \mathrm{Na}_{2} \mathrm{O}$ and $\mathrm{Al}_{2} \mathrm{O}_{3}$ content mostly

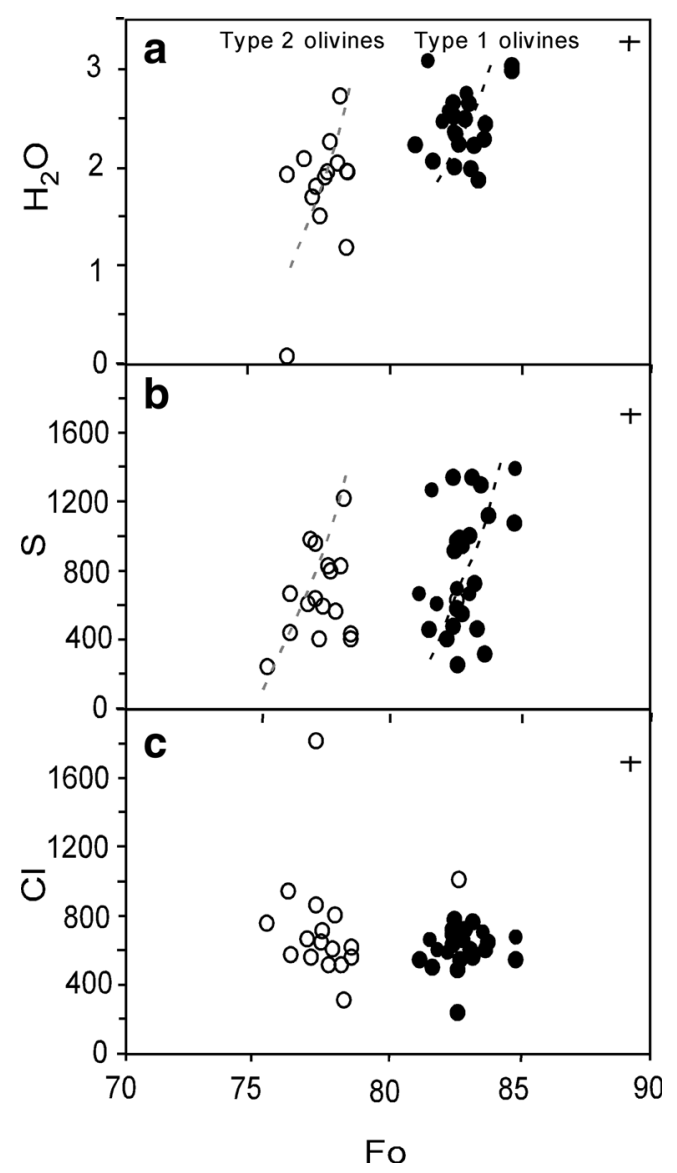

Fig. 10 Variation diagrams of a $\mathrm{H}_{2} \mathrm{O}$, b $\mathrm{S}$ and $\mathbf{c} \mathrm{Cl}$ versus olivine composition in olivine-hosted glass inclusions. Symbols as in Fig. 8. Water data as measured with micro-Raman technique. Crosses on the right top indicate the measurement error
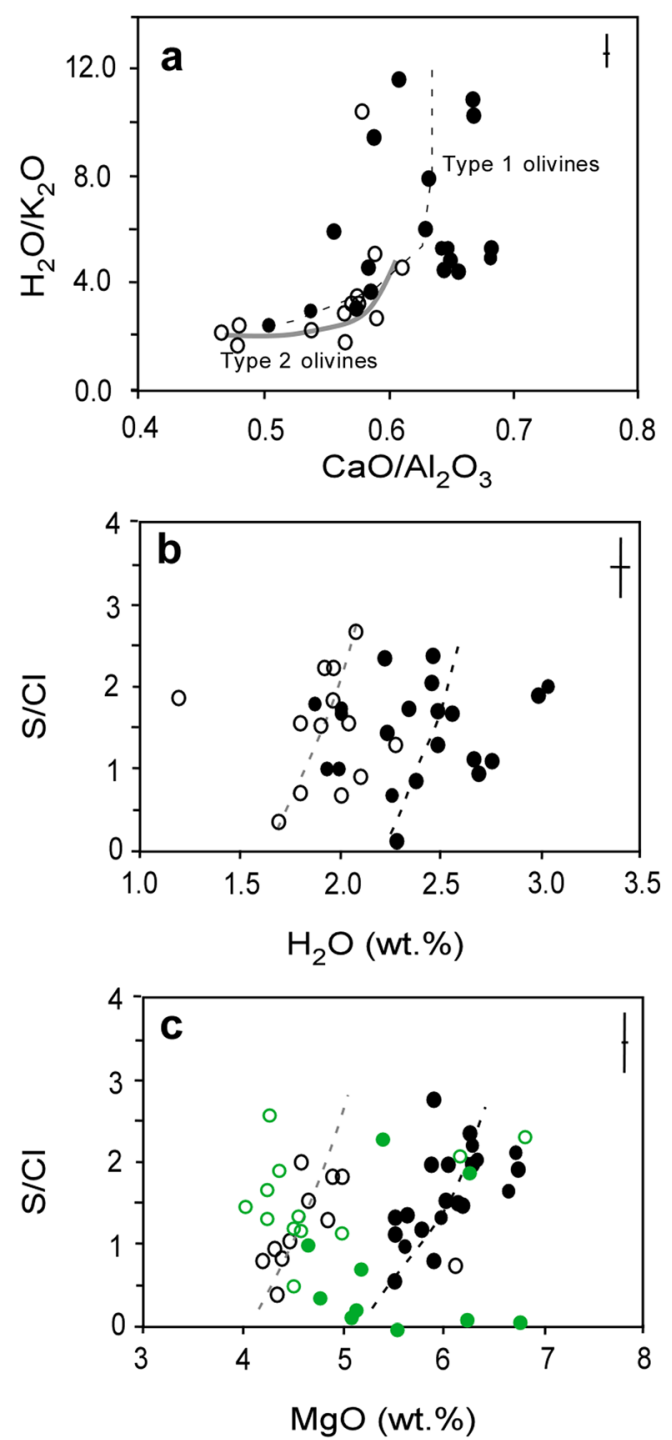

Fig. 11 a Variation diagram of $\mathrm{H}_{2} \mathrm{O}$ vs. $\mathrm{CaO} / \mathrm{Al}_{2} \mathrm{O}_{3}$. b $\mathrm{S} / \mathrm{Cl}$ vs. water content. c $\mathrm{S} / \mathrm{Cl}$ vs $\mathrm{MgO}$ content in olivine and plagioclase-hosted glass inclusions from Chaimilla scoria. Symbols as in fig. 8. Water data as measured with micro-Raman technique. Crosses at the right top indicate the measurement error

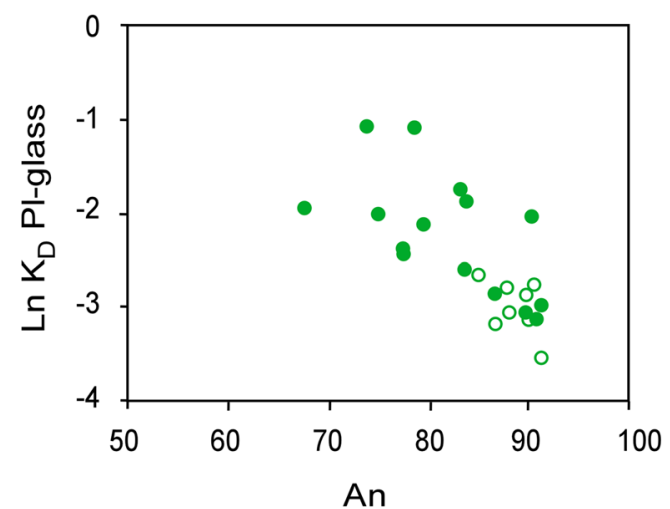

Fig. 12 Variation of $\mathrm{Kd}$ plagioclase-glass An content in plagioclasehosted glass inclusions. Symbols as in Fig. 8 
in LS scoria, a depletion related to massive plagioclase crystallization in these samples (Fig. 8).

Interestingly, all groundmass compositions follow the same trend for $\mathrm{CaO} / \mathrm{Al}_{2} \mathrm{O}_{3}$ and $\mathrm{K} 2 \mathrm{O} / \mathrm{Na}_{2} \mathrm{O}$, excepting groundmass glasses from unit $\mathrm{D}$; these show lower $\mathrm{CaO} / \mathrm{Al}_{2} \mathrm{O}_{3}$ ratios that are compatible with their olivine-hosted glass inclusions (Fig. 9) and suggest distinct syneruptive crystallization conditions.

All groundmass glasses are volatile-poor, with maximum measured concentrations of 80 and $110 \mathrm{ppm}$ for $\mathrm{Cl}$ and $\mathrm{S}$, respectively, and concentrations below detection limits in about $10 \%$ of the analyses.

\section{Thermometry and barometry}

The temperature range of magma crystallization was estimated based on olivine and glass inclusion compositions according to Putirka et al. (2007); we obtained temperature values that range between $1046{ }^{\circ} \mathrm{C}\left(\mathrm{Fo}_{77}, 1.7\right.$ water wt.\%) and $1113{ }^{\circ} \mathrm{C}\left(\mathrm{Fo}_{78}\right.$, 2.73 water wt.\%) in type 1 (LS) olivines and between $1099 \pm 10$ $\left(\mathrm{Fo}_{83}, 2.29\right.$ water wt.\%) and $1132 \pm 10{ }^{\circ} \mathrm{C}\left(\mathrm{Fo}_{85}, 3.00\right.$ water wt.\%) in type 2 (US) olivines. Analytical uncertainties led to an error of about $10{ }^{\circ} \mathrm{C}$ on the temperature estimations.

Minimum saturation pressures were estimated for the inclusions analysed with FTIR techniques by applying the Papale et al. (2006) model at the temperatures calculated as described above. Pressures obtained range from 37 to $91 \mathrm{MPa}$, with the highest pressures obtained from the LS melt inclusions that contain the highest $\mathrm{CO}_{2}$. The minimum pressures required to dissolve the water measured with the microRaman technique (and assuming complete exsolution of $\mathrm{CO}_{2}$ ) vary from 28 to $50 \mathrm{MPa}$ in LS and from 33 to $73 \mathrm{MPa}$ in the US. Since $\mathrm{H}_{2} \mathrm{O}$ solubility decreases with increasing dissolved $\mathrm{CO}_{2}$, the saturation pressures as calculated from the micro-Raman data represent minimum values. The possible effect of $\mathrm{CO}_{2}$ (and the uncertainty in pressure estimation) can be evaluated by comparing the results and the $\mathrm{H}_{2} \mathrm{O}-\mathrm{CO}_{2}$ solubility curves calculated both for typical type 1 and type 2 inclusion glasses, as computed with the Papale et al. (2006) model (Fig. 13).

\section{Discussion}

\section{Modeling magma evolution}

We applied the software MELTS (Ghiorso and Sack 1995; Asimow and Ghiorso 1998) to reproduce the liquid line of descent and obtain further insights into the evolution conditions of the Chaimilla magmas. We have simulated decompression and cooling of magmas with compositions corresponding to the most primitive glass (originally melt) inclusion from the US (i.e. V112Bol2). We have simulated the effect of variable oxygen fugacities and total (lithostatic)

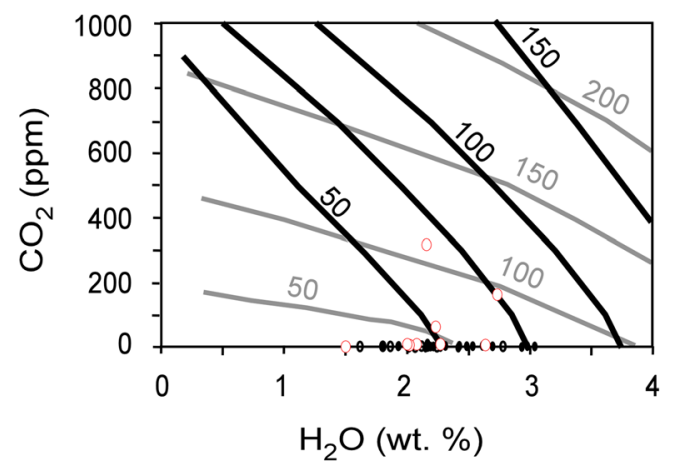

Fig. 13 Solubility of water and carbon dioxide for the average composition of olivine-hosted glass inclusion in the Chaimilla scoriae compared with water content measured with micro-Raman techniques (full circles US olivines and open circles LS olivines) and water and carbon dioxide content of selected inclusion as measured with FTIR techniques (open red circles). Isobaric grey lines correspond to the solubility of the inclusion within of type 2 olivines (average composition of US inclusions), and isobaric black lines correspond to the solubility of the inclusion within in type 1 olivines (average composition of LS inclusions)

pressures; both equilibrium and fractional crystallization processes were simulated using an initial water content of $3 \mathrm{wt} . \%$. In all cases, MELTS could not simulate the crystallization of olivine unless pyroxene crystallization was blocked; this is because MELTS tends to overestimate the stability of pyroxene at the expense of olivine (Villiger et al. 2004). In any case, it was able to predict liquid lines of descent that overlap with the observed glass-inclusion compositions in both the LS and US. In all experiments, plagioclase was the most abundant mineral phase crystallizing from the magma. The liquid line of descent for inclusions was best reproduced by crystallization of olivine and plagioclase through cooling from liquidus compositions (around $1200^{\circ} \mathrm{C}$, depending on water content) down to $1020{ }^{\circ} \mathrm{C}$ and depressurization from 120 to $62 \mathrm{MPa}$ with oxygen fugacity constrained by the QFM +1 curve (Fig. 8a). These results are in accordance with the oxygen fugacity estimated based on the olivine-spinel compositions, but they predict significantly higher pressures (and lower water solubility in the magmas) compared with the maximum solubility pressures obtained applying the Papale et al. (2006) model.

Compositions of olivine crystals obtained from the simulation, moreover, match well the real data for dissolved water content of 2 wt. $\%$ or lower. For higher contents, it predicts compositions Fo-poorer than the measured ones, probably due to the low water solubility allowed in these magmas by the MELTS libraries. For the same conditions, the model also predicts crystallization of $\mathrm{An}_{79-84}$ plagioclase during olivine crystallization and with more-evolved compositions (up to $\mathrm{An}_{75}$ ) in the final stages. When compared with the compositional variability of the melt inclusion data and plagioclase crystals, these data suggest that the An-rich plagioclase phenocrysts are compatible with crystallization from a magma 
with compositions corresponding to the less-evolved and water-richer ( $>2$ wt.\%) glass inclusions hosted within $\mathrm{Fo}_{82-83}$ olivines.

\section{Chaimilla magmas: degassing and evolution}

The petrologic features of the analysed scoriae show systematic variations among the magmas erupted during phases $\mathrm{C}$ and D (LS) and G and H (US) of the Chaimilla eruption, suggesting that they were fed by distinct magma batches.

Both plagioclase and olivine phenocrysts show a definite bimodality. Two components occur in different proportions in scoria from each unit: unit $C$ has both type 1 and 2 olivines ( 85 and $15 \%$ of our analyses, respectively) and type 1 and 2 plagioclases (20-80\% of our analyses, respectively). Unit D contains only type 1 olivines and both plagioclase types (occurring in equal proportions in our analyses). Units $\mathrm{G}$ and $\mathrm{H}$ have both type 1 and 2 olivine crystals as microphenocrysts and phenocrysts, respectively (occurring in equal proportions in our analyses) and only type 2 plagioclase crystals.

Melt inclusions hosted in type 2 (Mg-rich) olivine suggest that the crystals formed in a magma evolving by fractional crystallization of pyroxene and only minor olivine, associated with gradual magma degassing (from 3.1 to $2.4 \mathrm{wt}$.\% of water, 1400 to $300 \mathrm{ppm}$ of S and 2000 to $200 \mathrm{ppm}$ of $\mathrm{Cl}$ ). Inclusions hosted in type 1 ( $\mathrm{Mg}$-poorer) olivines show a compositional variability recording more extensive plagioclase and pyroxene (and minor olivine) crystallization and associated with more advanced degassing (from 2.5 to $1.0 \mathrm{wt}$ \% $\%$ of water, 1000-250 and 1800-200 ppm of $\mathrm{S}$ and $\mathrm{Cl}$, respectively). Inclusions hosted in An-rich cores of type 2 plagioclases have compositions matching the variability of olivine-hosted melt inclusions and higher $\mathrm{K}_{2} \mathrm{O} / \mathrm{Na}_{2} \mathrm{O}$ ratios in rims, whereas inclusions in type 1 plagioclase (reversely zoned) show more homogenous compositions, with almost constant $\mathrm{CaO} / \mathrm{Al}_{2} \mathrm{O}_{3}$ ratios of 0.5 and $\mathrm{K}_{2} \mathrm{O} / \mathrm{Na}_{2} \mathrm{O}$ ratios between 0.2 to 0.3 .

Geochemical trends recorded by Chaimilla glass inclusions and matrices can be explained by multiphase magma differentiation (through crystallization, cooling and degassing) associated with magma mixing. Two magma end members can be identified: first is a type 1 magma, which evolved from a melt with the same composition as the bulk Chaimilla scoria and was stored in a shallow reservoir (at around $2 \mathrm{~km}$ depth) where it was subjected to degassing and An-poor (type 1 plagioclase cores) plagioclase crystallization, associated with minor pyroxene and olivine (type 1) crystallization.

The second end member (type 2 magma) evolved from a basalt with compositions corresponding to the more primitive inclusions hosted in type 2 olivines. This magma mostly evolved through fractional crystallization of olivine and pyroxene accompanied by $\mathrm{S}$ and water (from 3 to $2 \mathrm{wt} . \%$ ) degassing during rise. A minor amount of An-rich ( $\left.\mathrm{An}_{94-84}\right)$ plagioclase crystallized, probably under undersaturated conditions.

The mineral assemblage in LS scoria, including type 1 and 2 olivines and both normally and reversely zoned (type 1 and 2) plagioclase, suggests mixing between the two magmas before eruption, probably due to the entrance of a small batch of crystal-poorer, water-richer, type 2 magma into the shallow reservoir where type 1 magma was crystallizing. Magma mixing caused a temperature increase in the reservoir with partial dissolution of An-poor plagioclases and further magma crystallization with formation of the An-rich rims in type 1 plagioclases. The deposits of the basal sequence reflect activation of the shallow system, causing vent opening and outgassing followed by vulcanian activity. These events further destabilized the reservoir and triggered the main explosive phase depositing the lower sequence, with almost complete emptying of the reservoir during the phase of eruption that deposited the middle sequence. Finally, a larger batch of type 2 magma fed the most explosive phase of the eruption, depositing the upper sequence and culminating with the repeated column collapses generating the PDC deposits of unit $\mathrm{H}$.

\section{Comparison with recent activity of Villarrica volcano}

At present, Villarrica is an open-conduit volcano that is persistently outgassing. The recent activity is characterized by a narrower compositional range and more uniform phenocryst composition (and content) than that which produced the Chaimilla products (Witter et al. 2004 and Gurioli et al. 2008). Olivine crystals are smaller in scoriae of the recent activity (reaching a maximum of $0.5 \mathrm{~mm}$ ) and Fo content corresponds to type 2 (Fo-poor) olivines in Chaimilla scoria (Fo ${ }_{76-79)}$. Chaimilla plagioclase crystals are larger and significantly more Ca-rich than the ones currently erupted $\left(\mathrm{An}_{58-60}\right.$ in year 2000 scoria), but have compositions similar to the most An-rich plagioclase $\left(\mathrm{An}_{80-85}\right)$ embedded in a lava flow emitted in 1984. No pyroxenes have been found in the recent products (Witter et al. 2004). Olivine-hosted and plagioclase-hosted glass inclusions from reticulites of the year 2000 explosions have similar $\mathrm{Mg \#}$ as do some of the inclusions hosted in type 2 (Fo ${ }_{76-77}$ ) olivines in the Chaimilla scoria, but with significantly less water (no more than $0.28 \mathrm{wt} . \%$ ) than in the Chaimilla magmas. Interestingly, the maximum water content of glass inclusions hosted in type 2 (Fo-poor) olivines is compatible with the initial water content predicted by Witter et al. (2004) for the recent magmas (i.e. 2 wt.\%), based on very similar olivine compositions.

Our data suggest very different crystallization and degassing conditions for the current activity of the volcano compared to that represented by products of the Chaimilla eruption, but similar parental magmas. Recent magmas, in fact, experience equilibrium crystallization and degassing in 
a very shallow reservoir $(<1 \mathrm{~km})$, at much lower $\mathrm{P}_{\mathrm{H} 2 \mathrm{O}}$ (17 MPa, as calculated by Witter et al. 2004), and a stable magmatic system is maintained for long periods by convection driven by outgassing (Witter et al. 2004). This was also suggested by geophysical and geochemical monitoring observations (Palma et al. 2008; Ripepe et al. 2010), by analogy with other open-conduit volcanoes (i.e. Stromboli: Landi et al. 2006; Mt Erebus: Caldwell and Kyle 1994). The Chaimilla magmas, instead, experienced crystallization during rise from greater depth (at pressures up to $120 \mathrm{MPa}$ ) and with higher dissolved water concentrations. Scoriae do not preserve direct information on the amount of volatiles still dissolved in the magma just before eruption, because groundmass glass is usually completely degassed. Crystal, glass and scoria composition are, however, reliable petrologic indicators for degassing processes. MELTS simulations show that the Na-richer plagioclase phenocryst rims are in equilibrium with magmas containing about $1.8 \mathrm{wt} . \%$ water and imply that a high fraction of the original water was still within the system just before syneruptive crystallization of microlites in the groundmass and possibly during fragmentation of the microlite-poor US magma. We suggest that these differences in magma ascent and degassing history played a primary role in causing the high explosivity of the Chaimilla eruption, and confirm the primary role of volatile content and magma ascent rate in controlling eruptive dynamics. Finally, we note that slightly different $\mathrm{Ba} / \mathrm{Nb}, \mathrm{Sr} / \mathrm{Ce}$ ratios in the Chaimilla magma could be indicative of a larger initial water content in the source magmas with respect to other Villarrica magmas. This hypothesis should be confirmed or rejected based on more-systematic trace-element studies on historical lava and tephra.

\section{Conclusions}

The Chaimilla eruption was the largest magnitude event produced by the Villarrica summit cone after the caldera-forming Pucón ignimbrite eruption $(3.7 \mathrm{ka}$ ) and was fed by inhomogeneous basaltic andesite magmas. The eruption dynamics were complex and produced four main sequences of events having different intensities. Our data show that the main changes in the eruption dynamics were associated with changes in the composition and petrology of the erupted magmas. The magmas erupted during the main phases (C-D and G-H) are characterized by petrological differences related to slightly different initial compositions, different degrees of crystallization, equilibrium conditions and magma ascent rates. The eruption was probably triggered by a mafic and volatile-rich input (with water up to $3.1 \mathrm{wt} . \%$ ) within a shallow magmatic reservoir (at about $1 \mathrm{~km}$ below the volcano) containing a more crystalline and degassed magma (about $1 \mathrm{wt} . \%$ water), which fed almost all of the (weaker) eruptive phases that produced the lower and middle sequences. The magma erupted during the more violent late phase that deposited the upper sequence, instead, experienced minor crystallization at shallow levels and less-efficient degassing, which are indicative of a rapid ascent of a larger magma batch from depths of about $3 \mathrm{~km}$ below the volcano. This hypothesis explains the increased explosivity of this phase of the eruption, characterized by higher intensity and repeated column collapses.

The Chaimilla scoriae also have bulk compositions similar to that of magma currently erupted at Villarrica, but there are marked differences in crystallinity, storage pressures and volatile contents (Witter et al. 2004). The current magmas have a much lower dissolved volatile content, indicating very shallow and stable crystallization and outgassing in open-vent conditions. We suggest that open-conduit conditions and low feeding rates are key factors in limiting the explosivity of the volcano in its current state, because they allow efficient outgassing and circulation of magma, favouring equilibrium crystallization and homogeneous properties of the magma body. On the other hand, the greater explosivity of the Chaimilla eruption was probably controlled by the storage of a significant volume of magma with intermediate volatile contents in a well-developed shallow reservoir and triggered by deep, hot and volatile-rich magma recharges.

Acknowledgments This work was supported by SNFS grants number 200021-116335 and 200021-122268. The authors are grateful to Oulfa Belhadj for her help in the olivine grains preparation for FTIR and microRaman analyses and to C. Bouvet de Maisonneuve and Y. Suzuki for fruitful discussions; R. Avanzinelli, K. Cashman and R. Cioni for constructive comments on a previous version of the manuscript; A. Mc Carthy for assistance during microprobe analyses; A. Martigner for assistance during SEM observations and A. Ulianov for assistance during collection and treatment of LA-ICP-MS data. We are also grateful to an anonymous reviewer and $\mathrm{M}$. Clynne for their constructive comments and J. Fierstein and J. White for editorial handling.

\section{References}

Anderson AT (1991) Hourglass inclusions: theory and application to the Bishop rhyolitic tuff. Am Mineral 76:530-547

Asimow PD, Ghiorso MS (1998) Algorithmic modifications extending MELTS to calculate subsolidus phase relations. Am Mineral 83: $1127-1132$

Baker RD (2008) The fidelity of melt inclusions as records of melt composition. Contrib Mineral Petrol 156:377-395

Blundy J, Cashman K (2005) Rapid decompression-driven crystallization recorded by melt inclusions from Mount St Helens volcano. Geology 33:793-796

Caldwell DA, Kyle PR (1994) Mineralogy and geochemistry of ejecta erupted from Mount Erebus, Antarctica, between 1972 and 1986. Ant Res Series 66:147-162

Cashman K.V (2004) Volatile controls on magma ascent and eruption. In: The State of the Planet: Frontiers and Challenges in Geophysics. AGU Geophys Monogr Series 150. Sparks R.S.J, Hawkesworth CJ (Eds), Washington DC, 109-124

Castruccio A, Clavero J, Rivera A (2010) Comparative study of lahars generated by the 1961 and 1971 eruptions of Calbuco and Villarrica 
volcanoes, Southern Andes of Chile. J Volcanol Geotherm Res 190: 297-311

Cervantes P, Wallace P (2003) Magma degassing and basaltic eruption styles: a case study of $\sim 2000$ years BP Xitle volcano in central Mexico. J Volcanol Geotherm Res 120:249-270

Clavero J, Moreno H (1994) Ignimbritas Licán y Pucón. Congreso Geológico Chileno, Concepción, Chile

Clavero J, Moreno H (2004) Evolution of Villarrica Volcano. In: Lara LE, Clavero J (eds) Villarrica Volcano $\left(39.5^{\circ} \mathrm{S}\right)$, Southern Andes, Chile. Servic Nac Geol Miner Bol 61:17-27

Costantini L, Pioli L, Bonadonna C, Clavero J, Longchamp C (2011) A late Holocene explosive mafic eruption of Villarrica volcano, Southern Andes: the Chaimilla deposit. J Volcanol Geoth Res 200: $143-158$

Danyushevsky LV, Sobolev AV (1996) Ferric-Ferrous ratios and oxygen fugacity calculations for primitive mantle derived melts: calibration of an empirical technique. Mineral Petrol 57:229-241

Del Carlo P, Pompilio M (2004) The relationships between volatile content and the eruptive style of basaltic magma: the Etna case. Annals Geophys 47(4). doi:10.4401/ag-4402

Di Muro A, Neri A, Rosi M (2004) Contemporaneous convective and collapsing eruptive dynamics: the transitional regime of explosive eruptions. Geophys Res Lett 31, L10607. doi:10.1029/ 2004GL019079

Erlund EJ, Cashman KV, Wallace, PJ, Pioli L, Rosi M, Johnson E, Delgado Granados H (2010) Compositional evolution of magma from Paricutin volcano, Mexico: the tephra record. J Volcanol Geoth Res 197:167-187

Ghiorso MS, Sack RO (1995) Chemical mass transfer in magmatic processes. IV. A revised and internally consistent thermodynamic model for the interpolation and extrapolation of liquid-solid equilibria in magmatic systems at elevated temperatures and pressures. Contrib Mineral Petrol 119:197-212

Goepfert K, Gardner JE (2010) Influence of pre-eruptive storage conditions and volatile contents on explosive Plinian style eruptions of basic magma. Bull Volcanol 72:511-521

Grove TL, Baker M, Price RC, Parman SW, Elkins-Tanton LT, Chatterjee N, Muentener O (2005) Magnesian andesite and dacite lavas from Mt. Shasta, northern California: products of fractional crystallization of $\mathrm{H}_{2} \mathrm{O}$-rich mantle melts. Contrib Mineral Petrol 148:542-565

Gurenko AA, Belousov AB, Trumbull RB, Sobolev AV (2005) Explosive basaltic volcanism of the Chikurachki Volcano (Kurile arc, Russia): insights on pre-eruptive magmatic conditions and volatile budget revealed from phenocryst-hosted melt inclusions and groundmass glasses. J Volcanol Geotherm Res 147:203-232

Gurioli L, Harris AJ, Houghton BF, Polacci M, Ripepe M (2008) Textural and geophysical characterization of explosive basaltic activity at Villarrica volcano. J Geophys Res 113, B08206. doi:10.1029/ 2007JB005328

Hamada M, Fuji T (2007) $\mathrm{H}_{2} \mathrm{O}$-rich island arc low-K tholeiite magma inferred from Ca-rich plagioclase-melt inclusion equilibria. Geoch $\mathrm{J}$ 41:437-461

Johnson E, Wallace PJ, Cashman KV, Delgado Granados H, Kent A (2008) Volatile contents and degassing induced crystallization at Volcan Jorullo, Mexico: implications for melt evolution and the plumbing system of monogenetic volcanoes. Earth Planet Sci Lett 269:478-487

Kamenetsky VS, Crawford AJ, Meffre S (2001) Factors controlling chemistry of magmatic spinel: an empirical study of associated olivine, Cr-spinel and melt inclusions from primitive rocks. J Petrol 42:655-671

Kamenetsky VS, Pompilio M, Métrich N, Sobolev AV, Kuzmin DV, Thomas R (2007) Arrival of extremely volatile-rich High-Mg magmas changes explosivity of Mount Etna. Geology 35:255-258

Landi P, Francalanci L, Pompilio M, Rosi M, Corsaro RA, Petrone CM, Nardini I, Miraglia L (2006) The December 2002-July 2003 effusive event at Stromboli volcano, Italy: insights into the shallow plumbing system by petrochemical studies. J Volcanol Geotherm Res 155: 263-284

Lara LE (2004) Overview of Villarrica Volcano. In: Lara LE, Clavero J (Eds), Villarrica volcano $\left(39.5^{\circ} \mathrm{S}\right)$, southern Andes, Chile. Servic Nat Geol Miner Bol 61: 5-12

Lohmar S, Robin C, Parada MA, Gourgaud A, López-Escobar L, Moreno H, Naranjo J (2005) The two major postglacial (13-14,00 BP) pyroclastic eruptions of Llaima and Villarrica volcanoes (Southern Andes): a comparison. 6th International Symposium on Andean Geodynamics, Barcelona, extended Abstracts pp 442-445

Lohmar S, Parada M, Gutierrez F, Robin C, Gerbe MC (2012) Mineralogical and numerical approaches to establish the preeruptive conditions of the mafic Lican Ignimbrite, Villarrica volcano (Chilean Southern Andes). J Volcanol Geoth Res 235-236:55-69

Maurel C, Maurel P (1982) Etude expérimentale de l'equilibre $\mathrm{Fe}^{2+}-\mathrm{Fe}^{3+}$ dans les spinelles chromifères et les liquids silicates basiques coexistants, à $1 \mathrm{~atm}$. CR Acad Sci Paris 295:209-212

Melnik O (2000) Dynamics of two-phase conduit flow of high-viscosity gas-saturated magma: large variations of sustained explosive eruption intensity. Bull Volcanol 62:153-170

Métrich N, Bertagnini A, Di Muro A (2010) Conditions of magma storage, degassing and ascent at Stromboli: new insights into the volcano plumbing system with inferences on the eruptive dynamics. J Petrol 51:603-626

Moreno H, Clavero J (2006) Geología del volcán Villarrica, Regiones de la Araucanía y de los Lagos. Servicio Nacional de Geología y Minería, Carta Geologíca de Chile, Serie Geología Básica, 98, 1 mapa escala 1:50.000, Santiago

Moreno H, Clavero J, Lara L (1994) Actividad explosiva post-glacial del Volcan Villarrica. Andes del Sur. Septimo Congreso Geologico Chileno. Universidad de Concepcion, Concepcion, Chile, pp 329333

Newman S, Stolper, EM, Stern RJ (2000) $\mathrm{H}_{2} \mathrm{O}$ and $\mathrm{CO}_{2}$ in magmas from Mariana arc and back arc systems. Geochem Geophys Geosyst 1: 1999GC000027

Palma JL, Calder ES, Basualto D, Blake S, Rothery DA (2008) Correlation between $\mathrm{SO}_{2}$ flux, seismicity and outgassing activity at the open vent of Villarrica volcano, Chile. J Geophys Res 113, B10201. doi:10.1029/2008JB005577

Papale P, Moretti R, Barbato D (2006) The compositional dependence of the saturation surface of $\mathrm{H}_{2} \mathrm{O}+\mathrm{CO}_{2}$ fluids in silicate melts. Chem Geol 229:78-95

Pichavant M, Mysen BO, Macdonald R (2002) Source and $\mathrm{H}_{2} \mathrm{O}$ content of high-MgO magmas in islands arc settings: an experimental study of a primitive calc-alkaline basalt from St. Vincent, Lesser Antilles arc. Geochim Cosmochim Acta 66:2193-2209

Putirka KD (2008) Thermometers and barometers for volcanic systems. In: Putirka KD, Tepely III (Eds.), Minerals, Inclusions and Volcanic Processes. Min Soc Am Geotherm Soc 61-120

Putirka K, Perfit M, Ryerson FJ, Jackson MG (2007) Ambient and excess mantle temperatures, olivine thermometry, and active vs passive upwelling. Chem Geol 241:177-206

Ripepe M, Bonadonna C, Marchetti E, Harris AJL, Pioli L, Ulivieri G (2010) Monochromatic infrasonic tremor driven by persistent degassing and convection at Villarrica volcano, Chile. Geophys Res Lett 37, L15303. doi:10.1029/2010GL043516

Rivera A, Corripio JG, Brock B, Clavero J (2008) Monitoring ice-capped active volcan Villarrica, southern Chile, using terrestrial photography, combined with automatic weather stations and global positioning systems. J Glacial 54:920-930

Roggensack K, Herving RL, McKnight SB, Williams SN (1997) Explosive basaltic volcanism from Cerro Negro volcano: influence of volatiles on eruptive style. Science 277:1639-1642 
Silva Parejas CS, Druitt TH, Robin C, Moreno H, Naranjo JA (2010) The Holocene Pucón of Volcán Villarrica, Chile: deposit architecture and éruption chronology. Bull Volcanol 72:247-259

Spilliaert N, Allard P, Métrich N, Sobolev AV (2006) Melt inclusion record of the conditions of ascent, degassing, and extrusion of volatile-rich alkali basalt during the powerful 2002 flank eruption of mount Etna (Italy). J Geophys Res 111:B04203

Sun SS, McDonough WF (1989) Chemical and isotopic systematics of oceanic basalts: implications for mantle compositions and processes. Geol Lond Spec Pub 42:313-345

Toplis MJ (2004) Thermodynamics of iron and magnesium partitioning between olivine and liquid: criteria for assessing and predicting equilibrium in natural and experimental system. Contrib Mineral Petrol 149:22-39

Van Daele M, Moernaut J, Silversmith G, Schmidt S, Fontijn K, Heirman K, Vandoorne W, De Clercq M, Van Acker J, Woff C, Pino M, Urrutia R, Roberts SJ, Vincze L, De Batist M (2014) The 600 yr eruptive history of Villarrica Volcano (Chile) revealed by annually laminated lake sediments. Geol Soc Am Bull 126:481-498
Vargas R, Moreno H, Lopez L, Frey F (1989) Geochemical variations in Andean basaltic and silicic lavas from the Villarrica-Lanin volcanic chain $\left(39.5^{\circ} \mathrm{S}\right)$ : an evaluation of source heterogeneity, fractional crystallization and crustal assimilation. Cont Mineral Petrol 103: 361-386

Villiger S, Ulmer P, Muntener O, Thompson AB (2004) The liquid line of descent of anhydrous, mantle-derived, tholeitic liquids by fractional and equilibrium crystallization- an experimental study at $1.0 \mathrm{GPa}$. J Petrol 45:2369-2388

Wehrmann H, Hoernle K, Garbe-Schonberg D, Jacques G, Mahlke J, Schumann K (2014) Insights from trace element geochemistry as to the roles of subduction zone geometry and subduction input on the chemistry of arc magmas. Int J Earth Sci 103:1929-1944

Wilson L, Sparks RSJ, Walker GPL (1980) Explosive volcanic eruptions IV. The control of magma properties and conduit geometry on eruption column behaviour. Geophys J R Astron Soc 63:117-148

Witter JB, Kress VC, Delmelle P, Stix J (2004) Volatile degassing, petrology, and magma dynamics of the Villarrica Lake, Southern Chile. J Volcanol Geotherm Res 134:303-337 